\title{
Improving Function Through Mosque Administration Reform at the Baiturrahman Banda Aceh Mosque
}

\author{
Halimah $^{1}$, Muhammad Iqbal ${ }^{2}$ \\ ${ }^{1,2}$ Lecturer in Jabal Ghafur Univerisity, Indonesia. \\ Ihalimah@unigha.ac.id, ${ }^{2}$ muhammadiqbal@unigha.ac.id
}

\begin{abstract}
Mosque is the center of the activities of Muslims. From there Muslims should design their future, both in terms of DIN Economics, politics, social and the whole joints of life, As its predecessors enable the mosque to its fullest extent. This is because the mosque has the ideal functions as a center of worship and culture of Muslims and have approximately 1100.000 units spread across Indonesia. However, this potential can't be well applied. Therefore, strategies are needed that can be used to improve function of mosque, one of the strategies that can be done is through administrative reform. One example of a fairly prominent mosque in improving their business functions through administrative reform is mosque of Baiturrahman Aceh. Since the mosque was inaugurated in 1612 to present (2019), it had been developed and improved. This study is descriptive qualitative research approach; focus on how the administrative reforms carried out and what are factors supporting and inhibiting the implementation of administrative reform at Baiturrahman Mosque Aceh in improving function.
\end{abstract}

Keywords: mosque; administrative reform

\section{Introduction}

Islam as the last religion and its teaching as a perfect complement make the elements in it should be used as a guideline. The undetachable element of Islam is the existence of a mosque that he as a specially designed building, positioned as a place of worship and as the center of every activity of Muslims. With this position is certainly a thing that is not new anymore is reordering and positioning the functions in place well. The existence of the expression of worship of Muslims certainly can not be separated with the existence of mosque buildings that are erected on the basis of Taqwa. From this because the mosque as the house of Allah SWT that serves as the place of all activities especially prayer five time and other prayers.

From the description displayed above is based also on the word found in the Qur'an letter at-Tawbah verse 108:

Do not pray in the mosque forever and ever. The mosque is established on the basis of Taqwa (the Mosque of Quba), since the first day is more appropriate for you to pray in it. Inside the mosque there are those who want to cleanse themselves. And indeed, Allah loves clean people.

This gives an insight that the construction of mosques not only based on Taqwa alone but he also as a follow-up in the cleansing of human psyche. Do not let the religious Indonesian citizen not contribute to the improvement of the country. One of the institutions of Muslims that can be utilized by stakeholders in addressing the problems of the nation is a mosque. This is because the mosque has an ideal function as a center of worship and culture for Muslims and the number of mosques spread in Indonesia is approximately 1100,000.

Sidi Gazalba (1975, H. 117-125) detailing the tasks of the ideal mosque that has been implanted by the Prophet, namely, as a place of prostration (place of prayer five time is obligatory and prayer is worth it), where to give and receive teaching Whether it is the science of religion or World science, the place to announce the important things pertaining to the life of Islam, the place of Baitul mal (Treasuries or Islamic cash), where the trial of the law and the judiciary, where to solve the problems of society and State Place of strategy and tactics of war, 
where the Penghulu leads the wedding ceremony and the place of judicial disputes of the household, where the body is turning, the social place is a place of residence for the traveler on the way, Where to read the Qur'an. When the existence of mosques and Musala is functioning as it should, as mandated by Rasulullah SAW, of course this will be a concrete solution. Yehia Hassan Wazeri (2017) added that traditional Islamic cities, mosques have function and hierarchy, and they are placed in a constant and standard distance from each other.

Therefore, it needs a synergistic effort between the government, the private sector and the community to improve the functioning of the mosque which will also affect the community improvement. One strategy that can be used as an alternative in the effort to improve the function of the mosque is through administrative reform. Administrative reform is a strategy that is commonly used to improve government institutions that are less productive in providing services to the community. One of the mosques that is quite prominent in the effort to improve its function is Baiturrahman Banda Aceh Mosque. Baiturrahman Banda Aceh Mosque doing various efforts to improve its function through administration reform strategy.

\subsection{Administrative reform}

Administration reform according to Soesilo Zauhar (2002:11), is a conscious and planned effort to change:

i) Bureaucratic structure and procedure (reorganization or institutional aspect).

ii) Bureaucrat attitudes and behaviors (behavioral aspects), to improve the effectiveness of the Organization or the creation of a healthy administration and ensure the achievement of national development.

While Carlos P. Ramos stated that administrative reform is increasing the effectiveness of the administration is closely related to the achievement of general goals of national development, because the success of administrative reform is misled by size Used by the state Government is developing in achieving development objectives. (In Soesilo Zauhar, 2002:14).

Based on the explanation above, it can be concluded the meaning of administrative reform that is the completion of administrative capabilities include efforts to address environmental problems, structural changes, changes in individual behaviour or groups The purpose of administrative reform is to improve the performance of individuals and groups and can achieve more economical, effective and faster objectives.

\subsection{Mosque}

Judging from the literal mosque means prayer place. The origin of the mosque itself from Arabic is Sajada (Fiil Madhi), which is then given the prefix ' $m a$ ', so that there is a meal where isim this meal causes a change in the form of Sajada Masjidu, mosque so that the meaning becomes place of prostration. The extension of the meaning becomes the place of Prayer (Sidi Ghazalba: 1994). In the Qur'an Allah explains, which means:

"Bertasbiam to Allah in the mosques that have been commanded to be glorified and called his name in it in the morning and evening, those who are not neglected by the business, nor by the sale, or any activity and Remembering God, and (from) establishing prayers, paying zakaah, they fear one day that (in that day) hearts and visions become shaken. "Qur'an 24:36-37.

The existence of the mosque can not be removed from the problem of prayer when based on the word of God above. So that everyone who wants to pray is allowed anywhere not 
in place. From the notion that the mosque above can be concluded that the building that is well arranged and specifically it is enabled in doing worship to Allah SWT.

\section{Research methods}

This type of research is a qualitative study with a descriptive approach. According to the Bungin (2010), it seeks to illustrate, summarize various conditions, situations, or various social reality phenomena that exist in the community that are the objects of research, and seek to attract the reality of the surface as A characteristic, character, trait, model, sign, or description of a specific condition, situation, or phenomenon.

\section{The Result of Research}

\subsection{Administrative reform aspect of organizational structure}

Administrative reform of the organizational structure aspect aims to create a better organizational structure than previous conditions in order to achieve organizational objectives. When an organizational structure is deemed to have been incompliant with the organizational development and organizational objectives, administrative reform of the organizational structure aspect must be undertaken. Baiturrahman Mosque started early 1612 until now (2019) has been conducting administrative reform on aspects of organizational structure. Administration on structural aspects

Baiturrahman Mosque begins when the mosque is only managed by a board that has not been legally established in the period 1612. After 1620 New Years the caretaker formed a foundation for managing mosques. The foundation is then called Baiturrahman Mosque. Baiturrahman Mosque Foundation from the first period of management (1620-2019) has conducted administrative reform on the aspect of the organizational structure. In the first period of management, Baiturrahman Mosque only serves as the manager of the mosque. However, now the management of Baiturrahman Mosque has expanded the function of its organizational structure. So that its management is not only limited to mosques. The parts of Baiturrahman Mosque in the period (2015-2019), among others:

1. Islamic Youth of Baiturrahman Mosque

2 Baiturrahman Education Institute

3. Baiturrahman Al-Qur'an Course

4. Health section

5. Muhtadin section

6. Building and Page Maintenance section

7. Hygiene section

8. Muslimah section

9. Security Section

10. Da'wah section

\subsection{Administration reform of human resources aspect}

Referring to the opinion of Hahn Been Lee (1968:3) stating that administrative reform is not only interpreted as improving the organizational structure, but also includes the improvement of the behavior of the people involved therein. Discussion of aspects of human resources that are important in the context of Baiturrahman is the recruitment of managers and 
the capacity building of the Baiturrahman Mosque's recruitment conducted so far focuses on two things, the first as regeneration Officers who have retired or passed away. Secondly, to fulfill the sturthe of an increasingly growing organization. Recruitment expected Baiturrahman Mosque has not been so much the most important thing to get people who have a great dedication to manage the mosque because of worship intentions. Not people who are just looking for income/material.

The capacity building of Baiturrahman Mosque is aimed to increase the understanding of mosque management both concept and technical. This is done, among other things, holding regular meetings every week to discuss the report and progress of the mosque, conducting ongoing trainings in various parts according to required needs and comparative study. In addition, Baiturrahman also work for the establishment of Islamic characters for its care.

\subsection{Administration reform aspects of innovation}

Innovation done in Baiturrahman Mosque is quite a lot but there are only some innovations that really have a considerable influence for the development of the mosque, among others:

1. Hold a Quranic course organized through the LPI

2. Conduct routine Islamic studies

3. Provide the service of vows in Islam and provide guidance specifically for the reverts

4. Facilitate adolescents

5. Provide consulting and counseling services

6. Receiving the guests for comparative study as a science transfer

\section{Conclusion}

Baiturrahman Mosque Aceh try to improve its function through the strategy of administrative reform taken with attention to three aspects, namely:

1. Aspect of human resources; This effort is carried out by hiring managers and improving the capacity of the Board through training and Comparative study.

2. Aspects of organizational structure; This effort is carried out by adjusting of the organizational structure in each of its periods and making the addition or reduction of tasks for each organ in the organizational structure.

3. Innovation aspects; This business is carried out by doing innovations especially related to the service to the mosque pilgrims

\section{References}

Al-Qur'an dan Terjemahan Departemen Agama RI, (Yayasan Penyelenggara Penerjemah Al-Qur'an). 2000.

Bungin, Burhan. 2010. Penelitian Kualitatif: Komunikasi, Ekonomi, Kebijakan Publik, dan Ilmu Sosial lainnya. Jakarta, Kencana

Ghazalba, Sidi. 1994. Masjid Pusat Ibadah dan Kebudayaan Islam. Jakarta: Pustaka Al- Husna. Lee, Hahn Been.1968. Korea: Time, Change and Administration. Honolulu, East-West Press. Yehia Hassan Wazeri. 2017. Exploring the Significance of Mecca Sacred Mosque Global Location. Journal Of Islamic Architecture No. 3.

Zauhar, Soesilo. 2012. Reformasi Administrasi: Konsep, Dimensi dan Strategi. Jakarta, Bumi Aksara. 